Working Papers on The Nature of Evidence: How Well Do 'Facts' Travel?

No. $22 / 07$

\title{
Apprenticeship and Training in Premodern England
}

\author{
Patrick Wallis
}

(C) Patrick Wallis

Department of Economic History

London School of Economics 
"The Nature of Evidence: How Well Do 'Facts' Travel?" is funded by The Leverhulme Trust and the ESRC at the Department of Economic History, London School of Economics.

For further details about this project and additional copies of this, and other papers in the series, go to:

http://www.Ise.ac.uk/collection/economichistory/

Series Editor:

Dr. Jon Adams

Department of Economic History

London School of Economics

Houghton Street

London, WC2A 2AE

Tel: $\quad$ +44 (0) 2079556727

Fax: $\quad$ +44 (0) 2079557730 


\title{
Apprenticeship and Training in Premodern England ${ }^{1}$
}

Patrick Wallis

\begin{abstract}
This paper re-examines the economics of premodern apprenticeship in England. I present new data showing that a high proportion of apprenticeships in seventeenth century London ended before the term of service was finished. I then propose a new account of how training costs and repayments were distributed over the apprenticeship contract such that neither master or apprentice risked significant loss from early termination. This new account fits with the characteristics of premodern apprenticeship, as well as with what is known about the acquisition of skills in modern and premodern societies.
\end{abstract}

\section{Introduction}

Apprenticeship was one of the most important means by which occupational training was supplied in pre-modern Europe. In England, non-agricultural apprentices made up between 7.5 and 10 percent of the labour force even in the eighteenth century. ${ }^{2}$ Elsewhere in Europe, apprenticeship had a comparable level of importance as the main route into skilled manufacturing, service and mercantile occupations. However, there is little consensus among historians about the structure and effects of premodern apprenticeship. Recently, S. R. Epstein suggested that what he saw as the success of apprenticeship in supplying technical training across Europe depended on craft guilds' ability to enforce the contracts between masters and their apprentices. ${ }^{3}$

\footnotetext{
${ }^{1}$ Earlier versions of this paper were much improved by comments from audiences at the LSE, Tokyo University, the EHA Annual Conference in 2005 and the IEHA conference in 2006, and the referees. I would like to thank Rosie Blau, Nick Crafts, Johan Dambruyne, Bert De Munck, Lars Edgren, Larry Epstein, Dan Raff, Tim Leunig, Joel Mokyr, Margaret Pelling, Maarten Prak, George Sheridan, Sigrid Wadauer and Nuala Zahedieh for particular advice or help. Keith Webb was very generous in sharing his data on London apprentices and guilds, as was Ian Galbraith in supplying this in the form used by the British Origins website. Olwen Myhill supplied the 1692 dataset created originally by James Alexander. I would also like to thank Catherine Wright and Carlos Brando for their research assistance.

${ }^{2}$ Humphries, "English apprenticeship", p. 81.

${ }^{3}$ Epstein, "Craft guilds". See also: idem, "Power", pp. 46-63; idem, "Apprenticeship".
} 
Jane Humphries has a similarly positive understanding of apprenticeship, suggesting that it "contributed to the premature exodus of labour out of agriculture that is the hallmark of English exceptionalism." She emphasises the effectiveness of several selfenforcing aspects of the apprenticeship contract, including but not limited to the activities of guilds in policing them, in buttressing this process at least into the eighteenth century. ${ }^{4}$ By contrast, Sheilagh Ogilvie argues that apprenticeship was mainly a device to exclude competition. Guilds, she suggests, were "neither necessary nor sufficient for ensuring craft skills." Her position extends a critique of both apprenticeship and guilds that goes back to Adam Smith and beyond. ${ }^{5}$

In this paper I re-examine the economics of premodern apprenticeship, focusing on England between the sixteenth and mideighteenth centuries. ${ }^{6}$ The standard account of apprenticeship describes apprentices spending the early part of their time in service receiving training before repaying their masters' investment by working at below-market (or no) wages for the remainder of their contractual terms. While this two-stage model is a useful simplification for some purposes, and may even come close to the reality of training in the late nineteenth and twentieth centuries, it is seriously flawed as an account of premodern apprenticeship. The problems with the standard account are both conceptual and empirical. The account bears little resemblance to our understanding of how occupational skills are acquired in practice, and it is inherently unsustainable if apprentices' fail to serve their full terms. Mortality and morbidity rates among apprentices present a

\footnotetext{
${ }^{4}$ Humphries, "English apprenticeship", p. 99

${ }^{5}$ Ogilvie, "Guilds", p. 312. See: Smith, Wealth of Nations, pp. 222-7; Rothschild, Economic Sentiments, pp. 87-112; Swanson: Medieval Artisans, p. 115; Earle, Making, p. 85.

${ }^{6}$ After the mid-eighteenth century, English apprenticeship changed noticeably: Snell, "Apprenticeship system", 313-321. I am also not considering the closely related, but distinct institution of pauper apprenticeship here. This appears to have often occurred when children were younger and with much less emphasis on acquiring a skill:

Sharpe, "Poor Children". Colonial American apprenticeship seems also to have taken on somewhat different characteristics: Grubb, "Statutory Regulation", 62-63.
} 
significant challenge to this system on their own. Even more significant, given the emphasis on contract enforcement in the literature, is the evidence I present here that apprentices in premodern England quit in large numbers, as I show for London in the 1690s in the first part of the paper.

I therefore suggest an alternative model of apprenticeship that could be sustainable in these circumstances. I argue that training was less intensive and more fragmented than in the standard account. Instead of preceding useful work, apprentices' training occurred in parallel with their engagement in profitable labour for their masters. This allowed a closer matching between the timing of the master's expenditure on training and the apprentice's repayment of these costs. Thus, both parties were less exposed to loss in cases of default. In this form, apprenticeship can survive in an environment in which quits are commonplace. Lastly, I briefly sketch out the consequences this has for our understanding of the effect of guilds on apprenticeship.

One finding that should be emphasised at the outset is the significant divergence that appears to have existed between premodern and modern apprenticeship structures. The standard account of the economics of apprenticeship appears to fit the evidence we have about nineteenth and twentieth-century training patterns. This suggests that shifts in employment structures, possibly the growth of large firms with its attendant shift in expectations among skilled workers about their likely contract duration, allowed employers to move to a more efficient training schedule in this period.

\section{Apprenticeship and its difficulties}

Early modern apprenticeship was a system of training in which young men, and less often young women, entered contracts to work for established craftsmen and merchants for a lengthy period, generally of some years, in exchange for instruction in a craft or trade. Beyond this 
common core, the terms of service and the manner of its arrangement differed across Europe, governed by a mix of law, custom and individual inclination. The key piece of legislation in early modern England was the Statute of Artificers (1562). ${ }^{7}$ This set out basic national rules for apprenticeship which were largely based around London's existing practices-all householders over 24 years can take apprentices, the term of service should be at least seven years, apprentices should be 24 or older when they finish and so on. The Statute also limited the practice of most non-agricultural occupations to those who had served an apprenticeship within that trade.

Although the arrangement of an apprenticeship contract was a matter of private negotiation, the incorporated towns and cities in England, and the guilds within them, generally established further requirements that helped them to record and govern apprenticeship. These practices were often direct imitations of London's well-known customs. Masters in such towns were thus normally required to register ("enrol") apprenticeship contracts with their guild and the urban authorities. This record would then provide the basis for an apprentice to become a freeman or citizen of the town after completing his termapprenticeship was the most common means by which citizenship was obtained in this period. ${ }^{8}$ Other criteria about the health, literacy, or social origins of apprentices, and their expected level of skill at the end of their terms, were sometimes added by guilds. Outside the corporate towns where the issue of citizenship did not apply, no system for registering apprentices' indentures existed, despite occasional proposals to establish one. This was a serious obstacle to the enforcement of laws limiting crafts and trades to those who had served apprenticeships

\footnotetext{
${ }^{7} 5$ Eliz. c. 4.

${ }^{8}$ Dunlop, English Apprenticeship, pp. 81-2; Lex Londinensis, 43-44; Earle, Making, 95; Britnell, Colchester, pp. 239-40; Phythian-Adams, Coventry, pp. 45, 83-4; Palliser, Tudor York, pp. 130, 149-50; Greaves, Leicester, pp. 50-3; Hughes, Lancaster, p. v; Millican, Norwich, pp. xii-xiv; Rowe and Jackson, Exeter, p. xxiv; Willis and Merson, Southampton, pp. xiv-xv.
} 
within them, even though, during the seventeenth century at least, all of the major English urban centres were still incorporated boroughs. Indeed, the constellation of rules around English apprenticeship never stopped a number of artisans from ignoring them in practice, although the scale of default is impossible to assess. ${ }^{9}$ Elsewhere in Europe the regulation of apprenticeship varied. In some areas, particularly many German regions, it was more tightly controlled by guilds; in others, such as parts of France and Spain, it largely remained a private contract between apprentice and master. ${ }^{10}$

By the seventeenth century in England, apprentices' families often paid a fee or "premium" to the master at the time of binding and gave bonds for their behaviour and honesty; apprentices' clothing and sometimes even their board might also be subsidised by their parents. ${ }^{11}$ Most apprentices, however, still lived as part of their masters' households and were given their board and lodging. They were rarely paid wages, although some did get gifts on completing their terms, and they might receive tips or pocket money during their service. ${ }^{12}$ Wages were even illegal in some cities: in 1527 London freemen were banned from paying apprentices wages, a policy restated as late as $1744 .{ }^{13}$ The length of apprenticeships also varied. In England, seven years was set as the legal minimum in 1563; shorter terms of three to five years seem

\footnotetext{
${ }^{9}$ Dunlop, English Apprenticeship, pp. 74-5; Davies, Enforcement, pp. 191-2, 206-7, 224

${ }^{10}$ Nicholas, "Child"; Epstein, Wage Labor; Kaplan, "L"Apprentissage"; Farr, Artisans, pp. 21-36; Ogilvie, .

${ }^{11}$ Apprenticeship terms are discussed in: Dunlop, English Apprenticeship; Brooks, "Apprenticeship"; Lane, Apprenticeship; Hovland, "Apprenticeship".

12 Merson \& Willis, Southampton Apprenticeship; Ralph and Hardwick, Calendar. Stephanie Hovland has found that such pay-offs were often equivalent to the fees required to obtain the freedom of an English town (personal communication). Wages were more common in the eighteenth century in England, and have also been observed in medieval Flanders: Rushton, "Matter in Variance", 96; Nicholas, "Child", pp. 1123-4; Epstein, Wage Labor, pp. 75-6, 110.

${ }^{13}$ Bohun, Privilegia Londini, p. 105; Welch, Pewterers, ii, 191. See also: Dunlop, English Apprenticeship, pp. 178-9.
} 
to have been more common elsewhere in Europe.${ }^{14}$ When the terms of indentures were broken, guild, civic and other legal bodies could intervene to resolve disputes, punish offenders and discharge apprentices if necessary. Some impression of the significance of apprenticeship can be gained from the numbers involved. Rappaport has estimated that roughly 10 percent of London's population in 1550 were apprentices, and two-thirds of all adult male Londoners at that time had served apprenticeships; by 1700, despite the city's rapid growth and the expansion of its more weakly regulated suburbs, apprentices still made up around 10 percent of the population. ${ }^{15}$

Compared to the debate over the economic consequences and institutions of apprenticeship, the internal economics of the system have been surprisingly uncontroversial. All modern commentators who explicitly consider the question of how apprenticeship training was paid for have subscribed to the same account. ${ }^{16}$ In this formulation, apprenticeship is an example of workers willingly funding their acquisition of general skills, as standard human capital theory would predict. Rather than taking payment upfront, the length of the contract allows masters to recoup the costs of the training they supply retrospectively, by having the skilled apprentice work at below-market wages for a sufficient period to equal the expense of their training these are the opportunity costs of time spent on instruction rather than work, the costs of materials and space used, and the apprentices' board and keep. An early version of this analysis was given basic graphical

\footnotetext{
${ }^{14}$ Dunlop, English Apprenticeship, p. 166-7; Kaplan, "L"Apprentissage"; Farr, Artisans; Steidl, "Silk Weavers".

${ }^{15}$ Rappaport, Worlds, pp. 232, 294; Schwartz, "London apprentices", p. 21.

${ }^{16}$ Elbaum \& Singh, "Economic Rationale", p. 603; Epstein, "Craft Guilds", pp. 690-91; Hamilton, "Enforcement", pp. 572-3; Hamilton, "Decline", pp. 642-3; Humphries, "English apprenticeship", p. 75; Rappaport, "Reconsidering", p. 260; Smits and Stromback, Economics of Apprenticeship, pp. 72-3.
} 
form in the 1930s (figure 1). ${ }^{17}$ This was a time when contemporary apprenticeship did seem to take this form. ${ }^{18}$ As the figure shows, in the early years of the contract the master's investment in the apprentice is greater than the value of labour they receive. The value of the apprentice increases with training until, at point $\mathrm{H}$, he becomes an asset. As R. B. McKerrow, the author of the diagram noted, his "initial value is the area FHDB minus the area CHE. (This ignores risk of death, \&c.)."

\section{FIGURE 1. The standard account of apprenticeship}

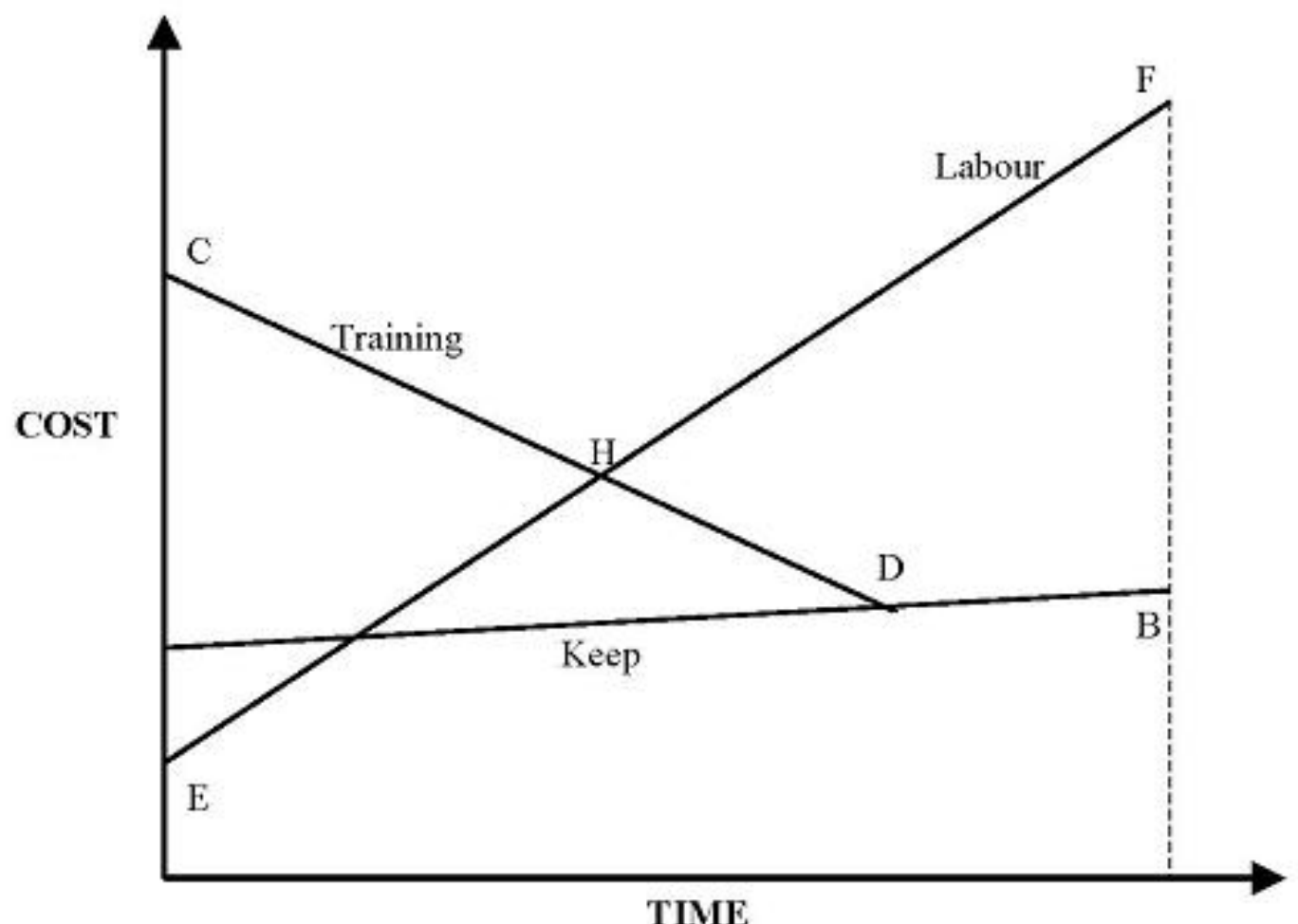

Source: Adapted from: Greg \& Boswell, Stationers' Company, p. xliii, n.1. I am grateful to lan Gadd for drawing my attention to this figure

The sequential distribution of training costs and repayment envisaged in this account of apprenticeship presents obvious risks for

\footnotetext{
${ }^{17}$ Another formal description, based on similar assumptions about the distribution of costs and training, but with board and keep represented as a constant wage, is given in Hamilton, "Market", p. 504 and idem, "Enforcement", pp. 572-3.

${ }^{18}$ Elbaum \& Singh, "Economic Rationale", p. 597, 598; Elbaum, "Apprenticeship", p. 343-4.
} 
both masters and apprentices. Early on, apprentices were vulnerable to exploitation by masters who could fail to provide sufficient or appropriate training. Conversely, once trained, apprentices who quit could capture the returns on their skill themselves, rather than repaying their masters' investment. This balance of tensions explains the focus in some recent studies of apprenticeship on how apprenticeship contracts could be written and enforced in such a way that the system would not collapse under the weight of opportunistic defaults. Epstein has suggested that guilds acted to prevent opportunism, while Humphries has identified various bulwarks for indentures, particularly the reputational and institutional enforcement mechanisms of family, guild and law, and the potential advantages of completion in future earnings and settlement rights. ${ }^{19}$ As she comments, "perhaps most important of all the completion of an apprenticeship marked a man out as trustworthy and dutiful." ${ }^{20}$ Both suggest that apprenticeship contracts worked, at least in the sense that opportunism was restrained and training was provided effectively. Yet while these analyses are plausible at first sight, there is remarkably little empirical evidence that apprenticeship contracts were, in fact, enforced.

In practice, early modern apprenticeship contracts do seem frequently to have ended early. One reason for this is the "death \&c" which McKerrow glossed over, for premodern apprenticeship inevitably coexisted with a significant risk of death and disability. Modern estimates suggest around 10 percent of apprentices died. ${ }^{21}$ Even more must have experienced serious sickness or disability.

More surprising are the high levels of early departure by apprentices. The first evidence that many apprentices did not complete their terms of service comes from the large numbers who failed to

\footnotetext{
${ }^{19}$ Epstein, "Guilds, apprenticeship"; Humphries, "English apprenticeship".

${ }^{20}$ Humphries, "English Apprenticeship", p. 90.

${ }^{21}$ Estimates of 10 percent include Rappaport, Worlds, p. 313; Ben Amos, "Failure", p. 155; Schwarz, "London apprentices". On sickness: Pelling, "Apprenticeship"; Pelling, Common Lot.
} 
become freemen or citizens in the town or city where they had trained (table 1). Apprenticeship was the main mechanism through which the freedom of towns was obtained, and becoming a freeman brought significant benefits - settlement and its associated right to poor relief, and the right to work at a trade in the town or city. ${ }^{22}$ Yet studies of a wide variety of guilds and towns across England have repeatedly found that fewer than half of apprentices became freemen. The contrast with completion rates of over 90 percent in England in the 1920s is dramatic. $^{23}$

TABLE 1: Percentage of apprentices who became freemen in England

\begin{tabular}{lccc}
\hline Location & Date & $\mathbf{N}$ & $\begin{array}{c}\text { Percentage } \\
\text { Becoming } \\
\text { freemen }\end{array}$ \\
\hline London & c.1450 & 4,568 & 43 \\
\hline & $1490-1599^{2}$ & 44,000 & 41 \\
\hline Bristol & $1633-1660^{3}$ & & 41 \\
\hline Norwich & $1560-1680^{4}$ & 2,442 & 30 \\
\hline Chester & $1510-1700^{5}$ & 5,835 & 17 \\
\hline Sheffield & $1558-1625^{6}$ & 183 & c.50 \\
\hline
\end{tabular}

Sources: ${ }^{1}$ Average of three guilds (Merchant Tailors, 1425-45, 1453-58; Goldsmiths, 1444-1500 Mercers, 1391-1464): Hovland, "Apprentices," p. 108. ${ }^{2}$ Fifteen guilds, 1490-1599: Rappaport, Worlds, pp. 311-12. ${ }^{3}$ Average of five guilds (N not reported): Masons, Carpenters, Stationers, Cordwainers, Drapers: Smith, "Social and Geographical Origins," pp. 197. Boulton finds the same completion rate for Southwark: Neighbourhood and Society, p. 104. ${ }^{4}$ All trades: Ben-Amos, "Failure," p.157. ${ }^{5}$ All guilds: Patten, "Patterns," p. 122. ${ }^{6}$ Leather crafts: Woodward, "Sources," p. $92 .{ }^{7}$ Cutlers: Unwin, "Apprenticeships," p. 197.

${ }^{22}$ Rules seeking to prevent non-freemen working in English towns were widespread: Dunlop, English Apprenticeship, pp. 78-82. See also: Ogilvie, State Corporatism, pp. 148-9, 157-8.

${ }^{23}$ Elbaum, "Apprenticeship", p. 340. See also: Smits and Stromback, Economics of Apprenticeship, pp. 27-8. 
These data are very far from perfect. They only capture apprentices who entered the freedom of their guild or town, rather than directly measuring completion rates. The process of becoming a freeman involved various costs - fees, gifts or other payments to guilds and urban authorities. While not always large, these served as a disincentive. The benefits it brought were most important to independent artisans and traders; even if they completed their apprenticeships, many aspirant freemen would then have to struggle to gather the resources to establish their own business. Entry to the freedom normally occurred several years after the end of apprenticeship. Most former apprentices presumably filled the gap by working legally as a journeyman while they saved, and many may never have worked in a more independent position that would have made the freedom worthwhile. Hence, freedom rates do not distinguish between apprentices who quit, those who completed but remained as journeymen, and those who completed and then migrated. Nonetheless, these low rates do at least raise the question of whether a significant proportion of apprentices might have left before the end of their term. ${ }^{24}$

We have limited amounts of more precise information about how many apprentices' left their masters early and when they did so. The only published work on the timing of departure explores early seventeenth-century Bristol, where Ben-Amos found that most of the apprentices for whom a time of departure was recorded left in the first two years of their term (59 of 99). Unfortunately, the sample is small and possibly unrepresentative: departure dates were recorded for only 5 percent of Bristol apprentices, whereas roughly 60 percent of them failed to become freemen. ${ }^{25}$ For London carpenters' apprentices between 1540 and 1590, the guild recorded their fate, but not the point

\footnotetext{
${ }^{24}$ On these transitions: Ben-Amos, "Failure", 159; Dunlop, English Apprenticeship, pp.46-47, 168-171; Farr, Artisans, pp. 34-6; Unwin, "Apprenticeships", 200-201; Stabel, "Guilds". Examples of post-apprenticeship migration are given in: Ben-Amos, "Failure", pp. 164-5.

${ }^{25}$ Ben-Amos, "Failure", p. 167
} 
at which it occurred: only 39.7 percent were freed. Of the rest, 14.6 percent died and 1.1 percent wed, thus voiding their indenture. The remaining 44.6 percent were simply described as "Gone," leaving the timing and manner of their departure unknown. ${ }^{26}$

For London apprentices in the 1690s, it is possible to get a better sense of when apprentices left. By linking tax and guild records, I identified a sample of freemen whose households were recorded in detail in a 1695 tax assessment. ${ }^{27}$ The apprentices these freemen had taken in the years before 1695 were obtained from guild records. ${ }^{28}$ । then examined the listings in the assessment to identify which of those apprentices whose contracted terms of service overlapped with the 1695 tax date were actually in residence with their masters at that time. This produced a sample of 166 apprentices bound to 97 masters in a range of London guilds.

Table 2 shows the percentage of apprentices still resident in their original masters' household, broken down by the time elapsed since their apprenticeship began. Overall, only 56 percent of apprentices were resident with their masters at the time of the tax. The decline over time in the percentage of apprentices who were still in service with their

\footnotetext{
${ }^{26}$ Rappaport, Worlds, p. 313.

${ }^{27} 6$ \& 7 Wm. \& M., c. 6. The details of the tax are discussed in Glass, London Inhabitants; the listings are: "1695 Marriage Assessment", London Metropolitan Archive. This was linked to the 1692 Poll Tax Assessment and the Association Oath Roll of 1695 so that companies could be identified and potential duplicates among guild members removed: J. Alexander, "1692 Poll Tax database", Centre for Metropolitan History; Webb, Association Oath (electronic version supplied by author). Each stage of linking used at least two identifiers from name, parish and occupation or company. The dataset only covers parishes within the walls.

${ }^{28}$ Masters in the sample came from a 24 different London companies. They were not equally distributed, because an initial trial run using manual linkage identified a large number from one company, the Apothecaries, who provide 34 percent of the masters and 31 percent of apprentices in the final sample. The remainder of the sample were linked using exact spelling matches. The effect of this on the argument is limited, as apothecaries' apprentices were more likely to be present (66 percent) than the overall average. The other companies in the sample were the Blacksmiths, Brewers, Farriers, Needlemakers, Pinmakers, Spectaclemakers, Cooks, Feltmakers, Founders, Masons, Pattenmaker, Tinplateworkers, Glassmakers, Ironmongers, Plumbers, Curriers, and Poulterers: Webb, London Apprentices (electronic version supplied by author).
} 
original master is clear and significant. ${ }^{29}$ It is also noticeable that even in the first year of their service a quarter of apprentices were missing. By the seventh year of their term, only 38 percent of apprentices were resident. The scale and timing of their departure suggests that apprentices quit throughout their term. It is not the case that apprentices were simply not taking the freedom. Nor is there an obvious cusp, which we might expect if they were leaving after a definable early training period had passed. Freedom records confirm the significance of the pattern of absences in the assessment listings: 40 percent of apprentices in the sample were later freed; this rises to 51 percent among apprentices who were resident. Only 25 percent of the missing apprentices later became freemen. ${ }^{30}$

These data present a fundamental problem for the standard account of apprenticeship. They suggest that indentures did not stop many apprentices leaving before the end of their terms, despite the available informal or formal enforcement mechanisms (given that indentures continued to be used, they did presumably serve some useful functions, plausibly in legitimating and defining the conditions of service). ${ }^{31}$ Similarly, other elements of apprenticeship contracts that have sometimes been interpreted as incentives for completion - payoffs at the end of terms, for example - were not enough to keep apprentices at work. ${ }^{32}$ This is, perhaps inevitably, data for a later period than one might hope for, particularly given the long-running debate over when the guilds lost their authority in England. Nonetheless, it seems that by most

\footnotetext{
${ }^{29}$ Significant at the 10 percent level. $P=0.063$.

${ }^{30}$ Freedom registers were checked for the four companies which provided the largest numbers of apprentice (123 of 187) in the sample: the Apothecaries, Vinters, Fishmongers and Carmen. 14 of 55 absent apprentices later became freemen.

${ }^{31}$ Desertion was a common complaint in suits by masters against apprentices, but the total volume of such law suits was tiny compared to the number of quits:

Rushton, "Matter in Variance", 94.

${ }^{32}$ Grubb convincingly interprets payoffs as limiting shirking by masters, however:

"Statutory Regulation", 61-2.
} 
indications, the 1690s safely predates the period when the guild system in London weakened seriously. ${ }^{33}$

Table 2: Percentage of apprentices with original master by year

\% with

$\begin{array}{cccc}\text { Year of } & \text { Apprentices } & \text { Apprentices } & \text { Original } \\ \text { service } & (\mathbf{N}) & \text { present (N) } & \text { Master } \\ 1 & 27 & 20 & 74.07 \\ 2 & 31 & 16 & 51.61 \\ 3 & 36 & 26 & 72.22 \\ 4 & 22 & 10 & 45.45 \\ 5 & 21 & 12 & 57.14 \\ 6 & 16 & 9 & 56.25 \\ 7 & 13 & 5 & 38.46 \\ \text { tals } & 166 & 98 & 59.04\end{array}$

Source: see text.

The levels of absence in Table 2 are, it should be emphasised, an upper bound estimate. As we have seen, some of those who were absent did later become freemen. Some of these apprentices may have been temporarily away when the tax assessment was taken, or deliberately concealed to reduce the tax payable; some may simply have been missed by the assessors. Others would have been working on their master's behalf elsewhere - a normal occurrence for many merchant's apprentices who often went abroad to act as factors for their masters and common in some trades connected to shipping. A few may have lodged elsewhere, although in this period apprentices still usually lived in their masters' households and there is no reason to suspect lodging habits varied over apprentices' terms in a way that might explain

${ }^{33}$ Kellett, "Breakdown"; Walker, “Guild Control”; Schwarz, London, pp. 210-11. 
the pattern in Table $2 .^{34}$ The status and role of male servants present in the household listings is another obvious gray area. In addition, there were also a further ten people described as "apprentices" by the tax assessors who could not be identified in guild records. These may have been apprentices who were present "on liking" - the trial period of between a month and a year that was common before formally contracting an apprenticeship - or simply cases missed in the guild records. More definite evidence of this practice is apparent in the five apprentices who were present in their masters household before they were officially bound, one nearly four years in advance of his enrolment. Indeed, they might have been illegally-kept apprentices, although if so it is somewhat surprising that they were described as apprentices to tax assessors.

Apprentices could also be "turned over" to new masters during their term, raising the possibility that some absent apprentices had moved rather than quit. Turning over was only occasionally recorded in guild apprenticeship registers. To obtain some sense of the scale of this, all non-family members listed as resident in masters' households were compared with lists of apprentices. This identified 18 individuals who had been indentured to different masters but who had since moved. ${ }^{35}$ As table 3 shows, these apprentices could have been turned over at any stage in their terms. This suggests that roughly 10 percent of all apprentices, or 22 percent of absent apprentices, had left by moving to another master rather than quitting, which fits with the

\footnotetext{
${ }^{34}$ A survey of Depositions and Bills and Answers in the Mayors Court produced evidence of the residence of 58 apprentices in the 1690s. All lived in their master's home. London Metropolitan Archive (hereafter LMA), CLA/024/05/016, CLA/024/07/81 Because the Court largely heard cases relating to relatively wealthy apprentices, Commissary Court depositions and Old Bailey Sessions Papers for the 1690 s were also reviewed. These contained far fewer indications of residence, 8 and 6 respectively, but again all apprentices lived in their master's home: LMA, DL/C244; www.oldbaileyonline.org (accessed 20 August 2007).

${ }^{35}$ The assessors often grouped apprentices and domestic servants under the common label of "servants". All servants were therefore checked against the apprenticeship lists to see if they had been bound to another master.
} 
freedom rates of missing apprentices discussed above. ${ }^{36}$ Unfortunately, given the limitations of the evidence it would be no more than guesswork to estimate the actual rate of departure. Nonetheless, the data does indicate that departures were likely to be significant in number and begin early.

Table 3: Years of service of turned-over apprentices resident with new masters

\begin{tabular}{ccc}
\hline $\begin{array}{c}\text { Years } \\
\text { elapsed }\end{array}$ & $\boldsymbol{N}$ & $\%$ \\
\hline 1 & 3 & 17 \\
\hline 2 & 3 & 17 \\
\hline 3 & 4 & 22 \\
\hline 4 & 3 & 17 \\
\hline 5 & 1 & 6 \\
\hline 6 & 4 & 22 \\
\hline 7 & 0 & 0 \\
\hline Total & $\mathbf{1 8}$ & $\mathbf{1 0 0}$ \\
\hline
\end{tabular}

Source: see text.

It is hard to establish why these apprentices' departed early. ${ }^{37} \mathrm{We}$ know that some apprentices slipped into vagrancy or a marginal existence while others departed when their masters' businesses could no longer support them. A number left after a breakdown in relations with their masters. ${ }^{38}$ Urban courts frequently heard cases in which apprentices and masters sought to be released from their indentures. Apprentices cited a range of failings among masters, including

\footnotetext{
${ }^{36}$ This assumes, of course, that inward and outward flows were the same.

${ }^{37} \mathrm{I}$ am intending in the future to carry out a full analysis of an expanded sample to see what light this can shed on this question.

${ }^{38}$ Archer, Pursuit, p. 15; Beier, "Social Problems", p. 215; Griffiths, Youth, pp. 32735.
} 
excessive correction, abuse, lack of training, and failing to supply food or clothing. Conversely, masters complained about apprentices' running away and refusing to return to their service, being drunkards, attacking them or their family, or embezzling money from the shop. ${ }^{39}$ Some masters pursued runaway apprentices and succeeded in forcing them to return or else had them punished. ${ }^{40}$ Such formal, and relatively costly, interventions are rare and even then many ended with an attempt at reconciliation. Unsurprisingly, a number of them clearly relate to attempts to recover a portion of the premium paid on binding. These cases, while striking, are likely to have been a small proportion of the total of departures. Court cases only occurred when apprentice or master resisted the ending of the contract. No trace would be left when master and apprentice jointly agreed to end their contract, which was probably the most common way terms ended early. In such situations, legal intervention was unnecessary: "the agreement of the master and apprentice," recorded under his master's hand was enough, as guides for Justices of the Peace made clear. ${ }^{41}$ For many masters and apprentices, it must have made sense to end contracts consensually rather than struggle to enforce the original terms.

Leaving their masters could be a positive decision for apprentices. The chance to learn a more suitable or advantageous trade, opportunities elsewhere, inheritances, marriage: all could draw an apprentice onto a different path. In larger cities, in particular, it seems likely that many apprentices always intended to curtail their term after acquiring skills. A few descriptions of their decisions survive. As BenAmos describes, one London shoemaker's apprentice, Benjamin Bangs

\footnotetext{
${ }^{39}$ See the records of the London Mayors Court, particularly the Interrogatories and Depositions, LMA, CLA/024/05/001-16.

${ }^{40}$ Ben-Amos, "Service", 63; Rushton, "Matter in Variance"; Morgan and Rushton, "Magistrate", pp. 64-5.

${ }^{41}$ With slight variation in wording, this is expressed in the numerous editions of the main guide from the early seventeenth century onwards. Compare for example the 1619 and 1742 editions: Dalton, Country Justice (1619), p. 74; Ibid, [1742], p. 136
} 
quit after three years because he "understood [his] business pretty well;" similarly a Bristol weaver's apprentice, John Mayes, left after three years to work in the countryside. ${ }^{42}$ As centres of skilled production, training in a large city offered a good basis on which to establish a business elsewhere. The apprentice could then move to another location where they might have useful connections, or perhaps simply face less competition. ${ }^{43}$ When the places where a craft could be practiced were legally constrained, as was the case for printing in England, which was restricted to London, and Oxford and Cambridge Universities, apprentices were significantly more likely to become freemen. Among stationers' apprentices, 60 percent taking the freedom, compared to an average of 45 percent for London apprentices at that time. ${ }^{44}$ Laws in England to prevent people practising most other trades without serving an apprenticeship were enforced patchily, particularly outside corporate towns with strong guilds, and might be circumvented through inherited rights or purchase, or by working as a journeyman. ${ }^{45}$

High levels of mortality, morbidity and departure had obvious implications for the standard account of costs and repayment across apprenticeship terms. If apprentices did not finish their terms, then they did not pay off the costs of their training; there was no transfer mechanism so that the loss suffered by one master might be offset from the benefits provided by those apprentices who did finish their terms, nor did most masters take enough apprentices over their careers that they could offset the losses from one against gains from another. In short, if apprenticeship worked as the standard account suggests,

\footnotetext{
${ }^{42}$ Ben-Amos, "Failure", p. 170. See also: Nicholas, "Child", p. 1125.

${ }^{43}$ The possible reasons and timing of apprentice departure are discussed in: BenAmos, "Failure", 161-166; Thrupp, "Gilds", p. 268; Rappaport, Worlds, pp. 314-5. ${ }^{44}$ Gadd, "Corporate Identity", p. 72

${ }^{45}$ Davies, Enforcement remains the only serious analysis of the enforcement of apprenticeship laws. Even in Middlesex, including the margins of London, prosecutions of artisans for working without apprenticeships were few in number (about twenty-four a year) in the later seventeenth century: Shoemaker, Prosecution, pp. 131-2.
} 
premodern master artisans were making a loss on many apprentices. The outcome surely should have been a breakdown in the system of training. Yet apprenticeship persisted.

\section{Reinterpreting Apprenticeship}

How did apprenticeship survive in the face of death and opportunistic departure? To construct an alternative analysis of apprenticeship that can fit these facts we need to consider both the nature of occupational skills and the organisation of premodern employment and production. In the standard model, it was assumed that training was general, and that it was therefore paid for by the apprentice since he or she will capture the returns through their later earnings, as suggested by standard human capital theory. This is plausible. ${ }^{46}$ Production in most crafts was highly fragmented, giving a wide range of possible employers, and many apprentices would later establish independent businesses. There was little likelihood that apprentices would remain in long-term employment with their master after completion, except in a handful of larger enterprises. Artisans were generally training future rivals not employees_and at the same time were revealing their client, credit and supplier networks to them. In these circumstances, few of the advantages identified to explain modern firms' investments in apprenticeship will apply. ${ }^{47}$

\footnotetext{
${ }^{46}$ As the skills apprentices' acquire are mostly trade-specific, it is technically more accurate to describe them as transferable skills of use to a large number of firms. However, in this situation, the incentives to invest in transferable skills approximate those for general skills: Stevens, "Theoretical Model"; idem, "Transferable training"; Humphries, "English apprenticeship", pp. 74-5. Epstein has suggested that because craft skills are transferable some of the costs of training will be born by the employer in the expectation of capturing some of the returns: Epstein, "Craft Guilds", p. 690. This seems to understate the market for skilled artisans.

${ }^{47}$ Cf. Acemoglu \& Pischke, "Why do firms train?". To some extent, the informational monopsony they propose as justification is a moot point here given premodern rates of non-completion: as they note, high quit rates among apprentices will produce low levels of investment by firms in general training. High quit rates and the low probability of future hiring also make the analysis in Malcolmson et al, "General training", inappropriate for this period. An excellent general survey is in Smits and Stromback, Economics of Apprenticeship, pp. 37-67.
} 
As this might suggest, a significant proportion of master craftsmen in some crafts and trades did not take apprentices. Many more took only one or two over their careers. Apprentices could have their uses, but they were not essential to many businesses even as a source of cheap labour. Small workshops had limited resources for training at the best of times-and apprentices added a further risk in bad times, for masters remained responsible for apprentices' upkeep even during business slumps or sickness. Clearly, apprentices had good reason to invest in their training; masters much less so. To be fair, apprentices could offer some long-run advantages to their masters. As natural additions to their social, economic and political networks, they might become creditors, collaborators, successors and supporters. ${ }^{48}$ However, the lustre of these possibilities was dimmed by the limited proportion of apprentices who remained in the location where they were trained. This balance of costs and benefits helps explain the size and variation of premiums paid by apprentices: the price of access to the best masters implies that masters demanded significant inducements before agreeing to take apprentices on. ${ }^{49}$

As the indirect and direct benefits from the training received during apprenticeship largely accrued to apprentices not masters, how did masters recover the costs of the instruction they supplied when they could not be sure of doing so retrospectively? To answer this, we must reconsider three of the key assumptions about the timing and allocation of costs and benefits in the standard model. These are that, firstly, apprentices need training before their labour is valuable; secondly, training is concentrated at the start of an apprenticeship; and, thirdly, training costs are high relative to the value of a new apprentices' labour, and that they must therefore be born, at least initially, by masters. Each of these assumptions is suspect.

\footnotetext{
${ }^{48}$ Kaplan, "L’Apprentissage"; Sonenscher, Hatters; Sacks, Widening, pp. 117, 167-8.

${ }^{49}$ Ben-Amos, Adolescence, pp. 87-9; Rappaport, Worlds, p. 311; Kaplan,

"L"Apprentissage", pp. 448-50.
} 
First, it is clear that regarding apprentices as callow youths, of little worth to a business until instructed, is misguided for most of our period. ${ }^{50}$ In early-modern England, apprentices were generally bound in their mid to late teens. ${ }^{51}$ From the outset, they could be set to a variety of unskilled yet necessary tasks, such as cleaning, carrying, deliveries, shop-watching and simple preparatory or processing jobs. They might also have some useful skills. Most would have been engaged in productive work in the household or their parent's workshop, farm or shop for years prior to entering service, giving them the chance to acquire skills that would later be useful to their new master. ${ }^{52}$ The most extreme example of this was youths from families involved in the same trade who might well have already obtained craft-specific skills before entering service. Contemporaries' recognition of the value of new apprentices' labour is apparent in official wage assessments from the sixteenth and seventeenth centuries which often included wages for apprentices in the building trades. Although paid to their masters, they underline the point that apprentices' work was worthwhile throughout their term. For example, London tilers' apprentices earned $11 \mathrm{~d}$ a day without food in 1589 , well above the $2.56 \mathrm{~d}$. necessary to provide a basic

\footnotetext{
${ }^{50}$ It may, of course, be more applicable for pauper apprentices in eighteenth century England, when those bound were often young children who may have had little experience of work.

${ }^{51}$ In late sixteenth-century London, the average age was 17.7 years: Rappaport, Worlds, p. XXX. For Bedfordshire children bound in London between 1500-1800, the average age was $17(n=4,524)$ : Cliff Webb, personal communication. The age of binding was to some extent determined by the existence of city rules preventing freedom before the age of twenty four.

${ }^{52}$ Ben-Amos, Adolescence, pp. 39-48; Ben-Amos, "Failure"; Pelling, Common Lot, pp. 110-111; Nicholas, "Child", p. 1104. Many were also literate: Rappaport, Worlds, pp. 298-99.
} 
diet at that time. ${ }^{53}$ Apprentices' status should not be confused with their ability. ${ }^{54}$

The second and third assumptions of the standard account, about the early concentration of training and its high costs, are best addressed together. Underlying discussions of apprenticeship are differing views of the expense and difficulty of training in preindustrial crafts and trades. Epstein, for example, maintains that craft skills were complex and hard to learn. By contrast, many others have shared Adam Smith's position that training was quick and simple. ${ }^{55}$ Given what we know of the theory of skill acquisition, it is likely that both views are partially correct: training could be quick and easy for masters, but learning might be hard and long for apprentices. Practising early-modern crafts and trades required a blend of tacit and propositional knowledge. Tacit knowledge is acquired through modelling, imitation, observation and experience. Didactic instruction is insufficient and sometimes ineffective in situations where skilled practitioners find it difficult to articulate how they perform some complex operations; instead immersion in practice is crucial. ${ }^{56}$ Instructing apprentices might thus demand very little time-consuming direct instruction from masters. Instead, the burden of acquiring a craft was put on the apprentice's diligence in observing and particularly practising skills. Of course, this process varied between crafts and individuals, but the speed of learning should not be exaggerated, and it should not be forgotten that apprentices needed to learn commercial as well as craft skills. Some element of instruction was, it seems, expected by apprentices, who did complain about masters who failed to provide

\footnotetext{
${ }^{53}$ Basic budget calculated from Boulton, "Food prices", tables 4, 6; Hughes and Larkin, Tudor, iii $40-42$. Wages varied between crafts and locations. Some specify apprentices over an age or level of experience; others include all apprentices. See: Knoop and Jones, "Masons and apprenticeship", p. 358; Minchinton, Wage Regulation, 25.

${ }^{54}$ Smith, "London Apprentices".

${ }^{55}$ Smith, Wealth of Nations, pp. 226-7; Farr, Artisans; Ogilvie, "Guilds".

${ }^{56}$ Polanyi, Personal Knowledge, p. 49; Hutchins, Cognition in the Wild, pp. 310-11l; Keller and Keller, Cognition and Tool Use, p. 156; Berry and Zoltan, Implicit Learning, pp. 26-8, 129-131; Rogoff and Gardner, "Adult Guidance", pp. 101-3.
} 
training. But it seems unlikely they envisaged intensive guidance that would substantially distract the master from more immediately productive work. This account of how skills are acquired has a further obvious implication: the distinction between periods of learning and periods of production largely dissolves. There are few points at which apprentices were not learning, even if they were not conscious of it themselves. ${ }^{57}$ Lest this seem too optimistic, it should be remembered that given the lengthy fixed minimum term of 7 years for an apprenticeship in England, the period of contracted service-if completed-might long outrun the period of training within which this balance of training and labour was necessary. In such cases, the profit from the apprentices' remaining time was simply a benefit to the master.

Evidence on modes of training in the past is unfortunately so limited that it is hard to establish firm conclusions in this area. Few accounts of apprenticeship survive, transmitting tacit knowledge is, almost by definition, a non-verbal process, and it was sufficiently universal as to attract little comment. However, those accounts we have - mostly from the eighteenth and nineteenth centuries -suggest that apprentices gradually acquired skills in their trade over a period of several years, often beginning with a period of relatively unskilled labour. Using diaries, court records and other sources, Peter Earle and Joan Lane have each revealed apprentices spending years opening shops, making deliveries or drinks, and cleaning, followed by similarly long stretches assisting skilled workers - shoemakers apprentices "closing" boots for example, or ribbon weavers apprentices helping to change patterns - before finally moving on to more skilled tasks. ${ }^{58}$ The

\footnotetext{
${ }^{57}$ Apprentices also sought to use alternative forms of training, sometimes independently from their masters, such as schooling, attending lectures, reading advice books or almanacs, or spending time with other masters. On schooling: BenAmos, Adolescence, p. 112. For specific examples, see: Brock, History, p. 46; Poynter, Journal, p. 52.

${ }^{58}$ For a good brief summary of descriptions from the eighteenth and nineteenth centuries: Lane, Apprenticeship, pp. 76-79. Earle discusses material from the London
} 
array of menial tasks that apprentices undertook would have extended the time it took them to learn the more skilled parts of a trade, but in the short-term this must have significantly increased their immediate value to their master. Throughout their term, apprentices combined useful work with learning, and only gradually moved from unskilled to skilled work.

It is at least suggestive that this analysis has parallels with the findings of modern anthropologists studying apprentice-type learning in traditionally organised crafts today ${ }^{59}$ They have generally found that apprentices are heavily engaged in productive work from the beginning, with little time dedicated specifically to training. Knowledge gained by apprentices might even be seen as "stolen." When learning pottery in Japan in the 1980s, one apprentice found herself spending hours cleaning the workshop and preparing clay, literally "earning the right to observe and learn by doing the menial scutwork of the master and the workplace"; direct tuition was almost non-existent, instead she was allowed to observe, practice on a very small scale, and only attempt more complex techniques after a long time in the workshop. ${ }^{60}$ This reliance on a "benign community of neglect" to supply instruction is a common experience. ${ }^{61}$ Among apprentice minaret builders in Yemen, for example, "much of learning process involves little or no verbal communication, the apprentice must rely on his/her eyes, ears, and sense of touch to incorporate their Master's skill into the reproduction of bodily representations of knowledge." ${ }^{\prime 62}$ Instruction is implicit and

\footnotetext{
Mayors Court Interrogatories on apprentices' learning experiences between c.1650 and c. 1700: Making, 95-100.

59 Dilley, "Ways of Knowing", pp. 33-4; Marshall, "Structural Constraints", 42-46; Coy, Apprenticeship; Lave and Wenger, Situated Learning; Simpson, "Apprenticeship", pp. 158-161.

${ }^{60}$ Singleton, Learning, p. 14. The description has striking parallels with apprenticeship in Roman Egypt, where one potter"s apprentices were not to try and make pots until they had watched the process for a long time; in the meantime, they were to work as servants in the shop: Westermann, "Apprentice contracts", p. 306.

${ }^{61}$ Lave \&Wenger, Situated Learning, p. 93.

${ }^{62}$ Marchand, Minaret Building, p. 138.
} 
fragmented. Questions are rarely posed, and reprimands rather than correction form the majority of feedback to apprentices.

If we take the potential value of apprentices' labour and the nature of their learning together, we find a quite different structure for premodern apprenticeships—one that could thrive amidst high levels of contractual default. Apprenticeship had four characteristics not recognised in the standard account: first, apprentices provided valuable labour services throughout their term, rather than repaying their masters' investment just in the later years of service. Second, any explicit instruction was likely to be delivered in fragments over a long duration. Third, most training was through observation, imitation and practice by apprentices that occurred while they were engaged in useful work-thus even apprentices' learning could even be productive. And fourth, the costs of supplying this training were low enough that they could be met by the value of less-skilled apprentices' work (at times in combination with a premium), even after the costs of their keep. In short, an apprentice's training occurred in paralle/ with their engagement in work that offset the costs of their keep and instruction. Premodern apprenticeship was not a two-stage process of costly training followed by repayment, but a time when work and training were often indistinguishable. ${ }^{63}$

With work and training intermingled, neither apprentice nor master was likely to loose out substantially when their relationship ended. Apprentices' value to their masters certainly fluctuated, depending on the level of training they received at any point and the value of their labour. They might also be able to advance the training curve through additional payments. As Defoe explained in the early eighteenth century, premiums exempted apprentices from "menial

\footnotetext{
${ }^{63}$ The problems of a two-stage training and work model in a competitive market are discussed in Acemoglu \& Pischke, "Beyond Becker", 118-119.
} 
offices, which were wont to be required of younger apprentices." ${ }^{\text {"64 }}$ Nonetheless, neither master nor apprentice was ever likely to be at risk of a large loss through opportunism. Inevitably, each did still face risks. For masters, there was the chance of theft, misbehaviour or future competition inherent in any employee. For apprentices, the potential losses from mistreatment or exclusion from the workshop were higher, particularly when a substantial premium had been paid. This supplies a further reason to expect that large premiums were accompanied by a quickening of the training schedule. Similar trade-offs are also implicit in agreements to repay all or part of the premium if an apprentice or master dies or moves; these generally indicate that repayment was only normally expected if this occurred during the early years of the term. ${ }^{65}$

Clearly, this slow training schedule does come at a cost to masters. By putting little effort into apprentices' training and obliging them to do useful but not instructive tasks, such as deliveries, cleaning, watching shops and the like, the time in which apprentices were most skilful and are thus most productive is reduced. As Epstein predicted "in the absence of credible bans against apprentice opportunism which took the shape of early departure....training would have been less then optimal and would have constrained output." ${ }^{\prime 66}$ This loss of productivity was the price of the systematic failure to prevent opportunistic departure (although it would be to some extent offset by the supply of very cheap labour for unskilled or semi-skilled tasks). One consequence of this was that when masters could enforce apprenticeship contracts then they should in theory advance the training schedule by offering more instruction, advice, time to practice and so on. This seems to have occurred in nineteenth century Britain, in parallel with the growth of

\footnotetext{
${ }^{64}$ Defoe, Complete, p. 148.

${ }^{65}$ Willis and Merson, Southampton, xvii-xvii.

${ }^{66}$ Epstein, "Guilds", p. 691.
} 
employment by large firms who could collectively police contracts through their hiring policies. ${ }^{67}$

This analysis obviously deals only with the basic costs of apprenticeship. Apprenticeship served a social as well as a training function. It was a period of socialization, of transition from youth to adulthood, and often from country or small town to city. Apprenticeship regulations served to reinforce the status and authority of masters, while formal apprenticeships underlined the importance of skill as the central aspect of the artisan's identity. ${ }^{68}$ Often, apprentice terms were in practice or theory determined by the age of majority, rather than the training needs of the individual. ${ }^{69}$ Similarly, a concern with controlling potentially disorderly youths seems also to have encouraged state sanction for long terms. These factors will cloud any attempt to calculate training values and labour costs.

\section{Institutions and Apprentices}

I have suggested that premodern apprenticeship operated in a way that would allow it to survive despite high levels of opportunistic early departure among apprentices. What, then, explains the institutional framework, particularly the guilds, that surrounded, and in some interpretations sustained, the system? Together with the evidence of low rates of completion discussed earlier, this analysis suggests that London guilds did not monitor or enforce apprenticeship contracts with

\footnotetext{
${ }^{67}$ Elbaum, "Apprenticeship", p. 342. Given premodern non-completion, "custom" may be a less powerful explanation for the survival of apprenticeship in England than has been suggested, cf: Elbaum, "Apprenticeship", pp. 340-342. The reverse seems to occur in nineteenth-century Canada, where a decline in the enforceability of contracts accompanied a steepening of the pay curve such that it matched apprentice productivity more closely: Hamilton, "Decline", pp. 652-3; Hamilton, "Enforcement". ${ }_{68}$ Brooks, "Apprenticeship", 74-8; Yarborough, "Apprentices"; Snell, "Apprenticeship", 303-6; Farr, Artisans, pp. 25-9, 33-4; Kaplan, "L"Apprentissage". Some recent anthropological work has similar concerns: Simpson, "Apprenticeship"; Marchand, Minarets.

${ }^{69}$ Similar provisions are found in Canada: Hamilton, "Enforcement", p. 561. This does of course also present a further problem for the traditional analysis of term lengths, in which duration is determined by training costs.
} 
any degree of success, at least by the late seventeenth century, and that apprenticeship thrived nevertheless. It is thus hard to accept that guilds primarily existed in order to provide enforcement for apprenticeship contracts. London may perhaps have been exceptional. However, the durability of apprenticeship as a system of training irrespective of the guilds is also apparent from the many examples of apprenticeship existing where guilds did not. ${ }^{70}$ It is hard to avoid the conclusion that guilds were not necessary for apprenticeship to work: co-existence did not imply dependence in this case. As Thrupp noted: "medieval artisan apprenticeship was a product not of gild monopoly, but of the family workshop." ${ }^{71}$

Of course, guilds did attempt to enforce apprenticeship contracts and influence the terms they contained. These measures were limited, however, to the area over which a guild had authority. This raises the question of why they sought to become involved with apprenticeship when it could survive without them - and what effect they had on its operation. The answer, as Smith and others have recognised, is that guilds' collective concerns with apprentices largely centred on restricting the numbers of people being trained in order to limit the workforce available to each master and control present and future competition. ${ }^{72}$ It was this anxiety about competition which meant apprenticeship was a concern of all masters, and by extension the guild: apprentice taking was not ubiquitous or smoothly distributed in guilds, but all masters were affected by decisions about labour concentrations in a craft. One

\footnotetext{
${ }^{70}$ Loats, "Gender", pp. 17-18; Nicholas, "Child", p. 1107; Clark, "Medieval Labor Law", p. 1108; Epstein, Wage Labor, p. 78; Howell, "Guild"; Crowston,

"Apprentissage". Apprenticeship without guilds was also widespread in colonial North America: Hamilton, "Market", p. 498.

${ }^{71}$ Thrupp, "Gilds", p. 264.

72 Dunlop, English Apprenticeship, pp. 45-46, 89; Rappaport, Worlds, p. 104-10;

Thrupp, "Gilds", p. 264; Nicholas, "Child", pp. 1108-9, 1114-5; Ogilvie, State Corporatism, 140-143; Ben-Amos, "Failure", 168; Crossley, Oxford, IV, 315; Unwin, "Apprenticeship", p. 202; Archer, Pursuit, pp. 127-8; Ashton, City, p. 57; Swanson, Medieval Artisans, p. 114; Britnell, Colchester, p. 186; Farr, Hands, p. 8. Lis \& Soly, "Irresistible Phalanx", p. 28.
} 
other consequence of guilds' efforts to limit numbers was the incentive it gave masters to default and take additional apprentices in secret. ${ }^{73}$

Guilds' impact on apprenticeship did go beyond policing numbers. They generally reserved the right to arbitrate disputes between masters and apprentices, which probably produced a persistent structural inequality in guild arbitration in favour of masters. ${ }^{74}$ They attempted to limit departed apprentices' opportunity for alternative employment, through rules against poaching. Perhaps most importantly, they also imposed arbitrary minimum terms on apprentices. Despite the varying needs of different crafts or different apprentices, even outside England terms seldom varied substantially between crafts with similar political clout in a region; variation across regions was, by contrast, more pronounced and underlines the rent-seeking aspect of guilds' involvement. $^{75}$

Locked into terms set without regard for ability or achievement, at least some of those apprentices who did serve out their contracts must have spent their later years working without compensatory training. Without these regulations, it seems likely that negotiation of terms to match the age and prior skills of apprentices would have produced a more equitable system. In early nineteenth century Paris, for example, Sonenscher found that "the length of an apprenticeship could vary from six months to six years in exactly the same trade." ${ }^{76}$ Similarly, as guilds weakened in England in the later eighteenth century, terms declined from an average of six or seven years to four years across a large range of trades. ${ }^{77}$

\footnotetext{
${ }^{73}$ Secret apprentices are, it is worth noting, a further reason to doubt Epstein"s view of guilds role in apprenticeship. If guilds were a positive regulatory force, then apprentices and masters had an incentive to register agreements with them.

${ }^{74}$ Humphries also notes this bias: "English Apprenticeship", p. 86.

${ }^{75}$ Ogilvie, State Corporatism, p. 140; Nicholas, "Child", pp. 1120-21.

${ }^{76}$ Sonenscher, Hatters , p. 35.

${ }^{77}$ Snell, Annals, p. 235.
} 
The attractions of these guild regulations to masters are obvious, and apprentices had little ability to resist such rules. As guilds existed in most major towns, there were few alternative centres of production where high-quality skills could be learned. One implication of the findings here is that the full burden of the arbitrary term of service was only born by a limited number of apprentices, although this included all those who hoped to later work legitimately in the area controlled by the guild; others could and did avoid these costs by departing early. The nature of these concerns also imply that guilds' involvement in apprenticeship might diminish or change in nature in several situations: where their ability to impose limits on apprentice numbers breaks down; if the scale of trade is no longer seen as fundamentally constrained; or if the occupational range of members of a guild becomes so diverse that members are more worried about external than internal competitors. These may suggest further reasons for the relationship between the decline of guilds and apprenticeship in England. ${ }^{78}$

\section{Conclusion}

This essay has sought to further the discussion Epstein opened by pointing out that "the economics of preindustrial apprenticeship has been virtually ignored" since Adam Smith. Having shown that levels of early departure among apprentices were almost as high as freedom statistics suggest, I have suggested a revised account of apprenticeship in which the delivery of training is kept in balance with payments in the form of labour or money from apprentices. Both were distributed across apprentices' terms so that high rates of early departure did not impose heavy penalties on masters. The effect of guilds on this was to extend the terms of service of those who did complete and restrict the numbers becoming apprentices in the first place. Guilds did not succeed in

\footnotetext{
${ }^{78}$ Smaller, more homogenous guilds experienced smaller falls in apprentice numbers than larger guilds in early eighteenth century London: Kahl, Development, pp. 28-9.
} 
enforcing what were, in practice, unenforceable contracts. Like many other areas of premodern regulation, the tidy hierarchy of the seven year apprenticeship leading to mastery was more ideal than reality.

This analysis suggests the need to modify the terms of the recent debate over guilds and apprenticeship. It is hard to reconcile very low completion rates and extensive use of apprenticeship outside guilds with Epstein's view that guilds were necessary to prevent opportunistic behaviour destroying the apprenticeship system. ${ }^{79}$ As Ogilvie has suggested for different reasons, the enforcement of apprenticeship is not a reason to rehabilitate the guilds. ${ }^{80}$ However, the high rates of noncompletion suggest that apprenticeship was undertaken as a more flexible period than the formalities of contracts and the simplifications of the traditional two-stage model of training would suggest. Guilds might seek to use apprenticeship as a "means for excluding outsiders." ${ }^{81}$ But for many apprentices, and their parents and friends, guilds' opportunistic rent-seeking did not outweigh the advantages of using this institution as a means of obtaining training and experience even if the formal contract was never completed. ${ }^{82}$ Seemingly, apprenticeship thrived despite, not because of, the guilds. In this regard, apprenticeship, even when not completed, could have still provided a key mechanism for the skill transfer and labour mobility that Epstein and Humphries have highlighted-at least so long as masters were still willing to provide training. Indeed, their interpretations of the economic effects of apprenticeship in Europe may actually be bolstered to the extent that non-completion was the result of apprentices actively seeking skills and engaging in ongoing migration in search of opportunities, as in part seems likely.

\footnotetext{
${ }^{79}$ Epstein, "Craft Guilds"; Humphries, "English Apprenticeship".

${ }^{80}$ Ogilvie, "Guilds", pp. 302-14.

${ }^{81}$ Ogilvie, "Guilds", p. 311.

${ }^{82}$ Cf. Humphries, "English Apprenticeship", p. 87.
} 
I have focused here on premodern England. However, much of the argument about the economics of apprenticeship is likely to be generally applicable across Europe, even though the particular forms of apprenticeship and its relationship to family, trade, corporate law and custom, and guild varied. Apprenticeship persisted in continental towns and regions with weak or no guild infrastructure to sustain indentures; continental masters faced the same general issues of how to instruct apprentices that English masters did; and mortality and morbidity rates alone meant that heavy early investment in training carried significant risks wherever one was based. Unfortunately, quit rates and evidence about the training and working patterns of apprentices are, it seems, as elusive for continental apprentices as they are for their peers in England. ${ }^{83}$

Preindustrial apprenticeship of the kind analysed here did not seem to survive the economic transitions of the eighteenth and nineteenth centuries. One factor in this in England was the extension of systems of parish apprenticeship, which placed pauper apprentices in a far more dependent and obviously exploited position. But informally structured apprenticeship, without employers concerning themselves greatly in training, will also tend to fail in larger organisations, where the scale of operation is greater, specialization is more extensive, and the distance of master and apprentice extends. This is apparent in some of the ways apprenticeship developed in the later nineteenth century. ${ }^{84}$

\footnotetext{
${ }^{83}$ There are indications that early departure was a problem in a number of locations, including Lyon (Garden, Lyon, p. 62), Paris (Sonenscher, Work, pp. 109-110), Flanders (Nicholas, "Child", pp. 1128-9; Stabel, "Guilds", pp. 200-201); Vienna (Steidl, "Silk Weavers") and Sweden (Edgren, "Crafts", p. 368-71). Figures vary widely, even for the same location. For Antwerp, completion rates for $17^{\text {th }}$ and $18^{\text {th }}$ century orphans (53 percent-61 percent), and $16^{\text {th }}$ century artists" apprentices (19 percent-27 percent) are low, while almost all $18^{\text {th }}$ century tinsmiths and plumbers finished their terms (95 percent) (De Munk, Leerpraktijken, pp. 286-293; Martens and Peeters, "Artists"). Ogilvie finds a large variation in freedom entry rates over time (between 52 percent and 90 percent) in response to changing circumstances in Württemberg: State Corporatism, pp. 157-8.

${ }^{84}$ Aldrich, "Apprentice", pp.20-21; Snell, "Apprenticeship".
} 
Apprenticeships in large firms took on quite different characteristics. ${ }^{85}$ These later changes in the context, form and structure of apprenticeship are perhaps also the explanation of why preindustrial apprenticeship has - with the exception of a few contrary voices - received such a bad press.

${ }^{85}$ Elbaum \& Singh, "Economic Rationale". 


\section{REFERENCES}

[Anon]. Lex Londinensis: Or, the City Law. London: Henry Twyford, 1680.

Acemoglu, Daron, and Jorn-Steffen Pischke. "Beyond Becker: Training in Imperfect Labour Markets." Economic Journal (1999): F112F142.

— .Why Do Firms Train? Theory and Evidence." Quarterly Journal of Economics 113, no. 1 (1998): 79-120.

Aldrich, Richard. "The Apprentice in History." In Apprenticeship: Towards a New Paradigm of Learning, edited by Patrick Ainley and Helen Rainbird, 14-24. London: Kogan Page, 1998.

Archer, Ian W. The Pursuit of Stability: Social Relations in Elizabethan London. Cambridge: Cambridge University Press, 1991.

_. "Politics and Government." In Cambridge Urban History of Britain. Volume Ii. 1540-1840, edited by Peter Clark. Cambridge: Cambridge University Press, 2000.

Ashton, Robert. The City and the Court, 1603-1643. Cambridge: Cambridge University Press, 1979.

Beier, A. L. "Social Problems in Elizabethan London." Journal of Interdisciplinary History 9, no. 2 (1978): 203-221.

Ben-Amos, Ilana Krausman. Adolescence and Youth in Early Modern England. New Haven: Yale University Press, 1994.

_. "Failure to Become Freemen: Urban Apprentices in Early Modern England." Social History 16 (1991): 155-172. 
- "Service and the Coming of Age of Young Men in Seventeenth Century England." Continuity and Change 3, no. 1 (1988): 41-64.

Berry, Dianne C., and Zoltan Paul Dienes. Implicit Learning :

Theoretical and Empirical Issues, Essays in Cognitive

Psychology. Hove: Lawrence Erlbaum Associates Ltd., 1993.

Boulton, Jeremy P. "Food Prices and the Standard of Living in London in The 'Century of Revolution,' 1580-1700." Economic History Review 53, no. 3 (2000): 455-492.

- Neighbourhood and Society: A London Suburb in the Seventeenth Century. Cambridge: Cambridge University Press, 1987.

Bohun, William. Privilegia Londini: Or, the Rights, Liberties, Privileges, Laws, and Customs of the City of London. third ed. London: John Walthoe jnr., 1723.

Britnell, R. H. Growth and Decline in Colchester, 1300-1525. Cambridge: Cambridge University Press, 1986.

Brock, W. H. The Fontana History of Chemistry. London: Fontana, 1992.

Brooks, C. W. "Apprenticeship, Social Mobility and the Middling Sort, 1550-1800." In The Middling Sort of People: Culture, Society and Politics in England, 1550-1800, edited by Jonathan Barry and C. W. Brooks, 52-83. Basingstoke: Macmillan, 1994.

Cerutti, Simona. "Group Strategies and Trade Strategies: The Turin Tailors Guild in the Late Seventeenth and Early Eighteenth Centuries." In Domestic Strategies: Work and Family in France 
and Italy, 1600-1800, edited by Stuart Woolf, 102-147.

Cambridge, 1991.

Clark, Elaine. "Medieval Labor Law and English Local Custom." The American journal of legal history 27, no. 4 (1983): 330-353.

Coy, Michael William. Apprenticeship: From Theory to Method and Back Again. Albany: State University of New York Press, 1989.

Crossley, Alan, and C R Elrington, eds. A History of the County of Oxford: Volume 4. The City of Oxford, 1979.

Crowston, C. H. "L'apprentissage Hors Des Corporations Les Formations Professionnelles Alternatives a Paris Sous L'ancien Regime." Annales Histoire Sciences Sociales 60, no. 2 (2005): 409-442.

Dalton, Michael. The Countrey Justice. London: 1619.

Davies, Margaret Gay. The Enforcement of English Apprenticeship. A Study in Applied Mercantilism, 1563-1642. . Cambridge MA.: Harvard University Press, 1956.

Davies, M. P. "The Tailors of London and Their Guild, c.1300-1500." D.Phil. diss., University of Oxford, 1994.

Davis, Natalie Zemon. "The Reasons of Misrule: Youth Groups and Charivaris in Sixteenth Century France." Past and Present, no. 50 (1971): 41-75.

Defoe, Daniel. The Complete English Tradesman. Gloucester: Alan Sutton, 1987. 
De Munck, B., "Leerpraktijken. Economische en sociaal-culturele aspecten van beroepsopleidingen in Antwerpse ambachtsgilden, 16de-18de eeuw." Ph.D. diss., Vrije Universiteit Brussel, 2002.

Dilley, Roy. "Ways of Knowing, Forms of Power." Cultural Dynamics 11, no. 1 (1999): 33-56. Dunlop, Olive Jocelyn, and Richard Douglas Denman. English Apprenticeship \& Child Labour. London, 1912.

Dunlop, Olive Jocelyn, and Richard Douglas Denman. English Apprenticeship \& Child Labour. London: T.F. Unwin, 1912.

Earle, Peter. The Making of the English Middle Class: Business, Society and Family Life in London, 1660-1730. London: Methuen, 1989.

Edgren, Lars. "Crafts in Transformation: Masters, Journeymen and Apprentices in a Swedish Towns, 1800-1850." Continuity and Change 1, no. 3 (1986): 363-384

Elbaum, Bernard, and N. Singh. "The Economic Rationale of Apprenticeship Training: Some Lessons from British and U.S. Experience." Industrial Relations 34, no. 4 (1995): 593-622.

Elbaum, Bernard. "Why Apprenticeship Persisted in Britain but Not in the United States." Journal of Economic History 49, no. 2 (1989): 337-349.

Epstein, Steven A. Wage Labor and Guilds in Medieval Europe. Chapel Hill: University of North Carolina Press, 1991.

Epstein, Stephan R. "Craft Guilds, Apprenticeship, and Technological Change in Preindustrial Europe." Journal of Economic History 58, no. 3 (1998): 684-713. 
- "Power, Resistance and Authorities: Craft Guilds and

Technological Change in Pre-Industrial Europe." In Guild-Hall and Government: An Exploration of Power, Control and Resistance in Britain and China, edited by Brian H. A. Ransom, 46-63. Hong Kong: David C. Lam Institute for East-West Studies Occasional Paper 97/09/OP 3, 1997.

_. "Apprenticeship." In The Oxford Encyclopedia of Economic History, edited by Joel Mokyr. Oxford: Oxford University Press, 2003, s.v.

Farr, James R. Artisans in Europe, 1300-1914. Cambridge: Cambridge University Press, 2000.

_. "Cultural Analysis and Early Modern Artisans." In The Artisan and the European Town, 1500-1900, edited by G. Crossick, 5674. Aldershot: Scolar Press, 1997.

- Hands of Honor. Artisans and Their World in Dijon, 1550-1650. Ithaca: Cornell University Press, 1988.

Gadd, Ian Anders. "Being Like a Field': Corporate Identity in the Stationers' Company, 1557-1684." D.Phil. diss., University of Oxford, 1999.

Garden, Maurice. Lyon Et Les Lyonnais Au Xviiie Siècle. Paris: Société d'édition Les Belles-lettres, 1970.

Glass, D. V. London Inhabitants within the Walls, 1695, London: London Record Society, vol. 2, 1966.

Greaves, R.W. The Corporation of Leicester 1689-1836. Oxford: Oxford University Press, 1939. 
Hughes, Thomas Cann, and W. B. Kendall. The Rolls of the Freemen of the Borough of Lancaster: 1688 to 1840, Lancashire and Cheshire Record Society, vol. 87, 1935.

Greg, W. W., and E. Boswell. Records of the Court of the Stationers' Company : 1576 to 1602 - from Register B. London: Bibliographical Society, 1930.

Griffiths, Paul. Youth and Authority: Formative Experiences in England, 1560-1640. Oxford: Clarendon Press, 1996.

Grubb, Farley. "The Statutory Regulation of Colonial Servitude: An Incomplete-Contract Approach." Explorations in Economic History 37, no. 1 (2000): 42-75.

Hamilton, Gillian. "The Decline of Apprenticeship in North America: Evidence from Montreal." Journal of Economic History 60, no. 3 (2000): 627-664.

—. "Enforcement in Apprenticeship Contracts: Were Runaways a Serious Problem? Evidence from Montreal." Journal of Economic History 55, no. 3 (1995): 551.

_. "The Market for Montreal Apprentices: Contract Length and Information." Explorations in Economic History 33, no. 4 (1996): 496-523.

Hanawalt, Barbara A. Growing up in Medieval London : The Experience of Childhood in History. New York: Oxford University Press, 1993.

Hey, David. The Fiery Blades of Hallamshire: Sheffield and Its Neighbourhood, 1660-1740, Communities, Contexts and Cultures. Leicester: Leicester University Press, 1991. 
Hovland, Stephanie R. "Apprentices in the Records of the Goldsmiths' Company of London, 1444-1500." Medieval Prospography 22, no. 1 (2001): 89-114.

- Hovland, Stephanie Ruth. "Apprenticeship in Later Medieval London, (C. 1300 - C. 1530)." PhD Thesis, University of London, 2006.

Howell, Martha. "Achieving the Guild Effect without Guilds: Crafts and Craftsmen in Late Medieval Douai." In Les Metiers Au Moyen Age: Aspects Economiques Et Sociaux, edited by Jean -Pierre Sosson and Pascale Lambrechts, 109-128. Louvain-la-Neuve: Universite Catholique de Louvain, 1994.

Hughes, Paul Lester, and James F. Larkin. Tudor Royal Proclamations. 3 vols. New Haven: Yale University Press, 1964.

Humphries, Jane. "English Apprenticeship: A Neglected Factor in the First Industrial Revolution." In The Economic Future in Historical Perspective, edited by Paul A. David and Mark Thomas, 73-102. Oxford: Oxford University Press, 2003.

Hutchins, Edwin. Cognition in the Wild. Cambridge, Mass: MIT Press, 1995.

Kahl, W. F. The Development of the London Livery Companies: An Historical Essay and a Select Bibliography. Cambridge MA.: Harvard Graduate School of Business Administration, 1960.

Kaplan, Steven L. "L'apprentissage À Paris Au Xviiie Siècle." Revue d'Histoire Moderne et Contemporaine 40, no. 3 (1993): 436-479. 
Keller, Charles M., and Janet Dixon Keller. Cognition and Tool Use : The Blacksmith at Work, Learning in Doing. Cambridge ; New York, NY: Cambridge University Press, 1996.

Kellett, J. R. "The Breakdown of Gild and Corporation Control over the Handicraft and Retail Trade in London." Economic History Review 10, no. 3 (1957-8): 381-394.

Knoop, Douglas, and G.P. Jones. "Masons and Apprenticeship in Mediaeval England." Economic History Review 3, no. 3 (1932): 346-366.

Lamour, R. "A Merchant Guild of Sixteenth-Century France: The Grocers of Paris." Economic History Review 2nd series, 20 (1967).

Lane, Joan. Apprenticeship in England, 1600-1914. London: UCL Press Ltd, 1996.

Lave, Jean, and Etienne Wenger. Situated Learning: Legitimate Peripheral Participation. Cambridge: Cambridge University Press, 1991.

Lis, Catherine, and Hugo Soly. "'An Irresistible Phalanx': Journeymen Associations in Western Europe, 1300-1800." International Review of Social History 39, no. Supplement 2 (1994): 11-52.

Loats, Carol L. "Gender, Guilds, and Work Identity: Perspectives from Sixteenth-Century Paris." French Historical Studies 20, no. 1 (1997): 15-30.

Malcomson, J. M., J. W. Maw, and B. McCormick. "General Training by Firms, Apprentice Contracts, and Public Policy." European Economic Review 47, no. 2 (2003): 197-227. 
Marchand, Trevor H. J. Minaret Building and Apprenticeship in Yemen. Richmond, Surrey: Curzon Press, 2001.

Marshall, H. "Structural Constraints on Learning." In Learning to Work, edited by Blanche Geer. Beverly Hills: Sage, 1972.

Martens, M.P.J., and Natasha Peeters. "Artists by Numbers: Quantifying Artist's Trades in 16th Century Antwerp." In Making and Marketing: Studies of the Painting Process in Fifteenth- and Sixteenth- Century Netherlandish Workshops, edited by Molly Faries. Turnhout: Brepols, 2006.

Merson, Allan Leslie, and Arthur James Willis. A Calendar of Southampton Apprenticeship Registers, 1609-1740.

Southampton: Southampton Records Series. Vol. 12, 1968.

Millican, Percy. The Register of the Freemen of Norwich 1548-1713. Norwich: Jarrold, 1934.

Minchinton, Walter Edward, ed. Wage Regulation in Pre-Industrial England. Newton Abbot: David \& Charles, 1972.

Morgan, Gwenda and Peter Rushton. "The Magistrate, the Community and the Maintenance of an Orderly Society in Eighteenth-Century England." Historical Research 76, no. 191 (2003): 54-77.

Nicholas, David. "Child and Adolescent Labour in the Late Medieval City: A Flemish Model in Regional Perspective." English Historical Review 110 (1995): 1103-1131.

Ogilvie, Sheilagh. State Corporatism and Proto-Industry: The Württemberg Black Forest, 1580-1797. Cambridge: Cambridge University Press, 1997. 
- "Guilds, Efficiency, and Social Capital: Evidence from German Proto-Industry." Economic History Review 57, no. 2 (2004): 286333.

Palliser, D. M. Tudor York. Oxford: Oxford University Press, 1979.

Pelling, Margaret. "Apprenticeship, Health and Social. Cohesion in Early Modern London." History Workshop Journal 37, no. 1 (1994): 3356.

- The Common Lot: Sickness, Medical Occupations and the Urban Poor in Early Modern England. London: Longmans, 1998.

Phythian-Adams, Charles. Desolation of a City: Coventry and the Urban Crisis of the Late Middle Ages. Cambridge: Cambridge University Press, 1979.

Polanyi, Michael. Personal Knowledge: Towards a Post-Critical Philosophy. London: Routledge \& Kegan Paul, 1962.

Poynter, F. N. L., ed. The Journal of James Younge (1647-1721) Plymouth Surgeon. London, 1963.

Ralph, Elizabeth, and Nora M. Hardwick. Calendar of the Bristol Apprentice Book, 1532-1565, Part II, 1542-1552. Bristol Record Society, vol 33, 1980.

Rappaport, Steve. Worlds within Worlds: Structures of Life in SixteenthCentury London. Cambridge: Cambridge University Press, 1989.

_. "Reconsidering Apprenticeship in Sixteenth-Century London." In Renaissance Society and Culture, edited by John Monfasani and Ronald G. Musto, 239-261. New York: Italica Press, 1991. 
Rothschild, Emma. Economic Sentiments: Adam Smith, Condorcet, and the Enlightenment. Cambridge, MA: Harvard University Press, 2001.

Rogoff, Barbara, and Gardner William. "Adult Guidance of Congitive Development." In Everyday Cognition: Its Development in Social Context, edited by Barbara Rogoff and Jean Lave, 95-116. Cambridge MA.: Harvard University Press, 1984.

Rowe, Margery M., and Andrew M. Jackson. Exeter Freemen, 12661967. Exeter: Devon and Cornwall Record Society, v. 1, 1973.

Rushton, Peter. "The Matter in Variance: Adolescents and Domestic Conflict in the Pre-Industrial Economy of Northeast England." Journal of Social History 25, no. 1 (1991): 89-107.

Sacks, David Harris. The Widening Gate: Bristol and the Atlantic Economy, 1450-1700. Berkeley: University of California Press, 1991.

Schwarz, Leonard. "London Apprentices in the Seventeenth Century: Some Problems." Local Population Studies 38 (1987): 18-22.

- London in the Age of Industrialisation: Entrepreneurs, Labour Force and Living Conditions, 1700-1850. Cambridge: Cambridge University Press, 1992.

Sharpe, Pamela. "Poor Children as Apprentices in Colyton, 15981830." Continuity and. Change 6 (1991): 253-270.

Shoemaker, R. B. Prosecution and Punishment: Petty Crime and the Law in London and Rural Middlesex, C.1660-1725. Cambridge: Cambridge University Press, 1991. 
Simpson, Edward. "Apprenticeship in Western India." Journal- Royal Anthropological Institute 12, no. 1 (2006): 151-171.

Singleton, John, ed. Learning in Likely Places: Varieties of Apprenticeship in Japan. Cambridge: Cambridge University Press, 1998.

Smith, Adam. An Inquiry into the Nature and Causes of the Wealth of Nations. 2 vols. Edited by Andrew Skinner. London: Penguin, 1999.

Smith, S. R. "The London Apprentices as Seventeenth-Century Adolescents." Past and Present 61 (1973): 149-161.

- "The Social and Geographical Origins of the London Apprentices, 1630-60." Guildhall Miscellany 4 (1973): 195-206.

Smits, Wendy, and Thorsten Stromback. The Economics of the Apprenticeship System. Cheltenham: E. Elgar, 2000.

Snell, K. D. M. Annals of the Labouring Poor: Social Change and Agrarian England, 1660-1900. Cambridge: Cambridge University Press, 1985.

—. "The Apprenticeship System in British History: The Fragmentation of a Cultural Institution." History of Education 25, no. 4 (1996): 303-322.

Sonenscher, Michael. The Hatters of Eighteenth-Century France. Berkeley: University of California Press, 1987.

-Work and Wages: Natural Law, Politics and the EighteenthCentury French Trades. Cambridge: Cambridge University Press, 1991. 
Stabel, Peter. "Guilds in Late Medieval Flanders: Myths and Realities of Guild Life in an Export-Oriented Environment." Journal of Medieval History 30, no. 2 (2004): 187-212.

Steidl, Annemarie. "Silk Weaver's and Purse-Maker's Apprentices in $18^{\text {th }}$ and $19^{\text {th }}$ Century Vienna." In Learning on the Shop Floor: Historical Perspectives on Apprenticeship, edited by Bert De Munck, Steven L. Kaplan and Hugo Soly, London: Berghan, forthcoming.

Stevens, Margaret. "A Theoretical Model of on-the-Job Training with Imperfect Competition." Oxford Economic Papers 46, no. 4 (1994): 537-562.

_. "Transferable Training and Poaching Externalities." In Acquiring Skills: Market Failures, Their Symptoms and Policy Responses, edited by A. L. Booth and D. J. Snower, 19-40. Cambridge: Cambridge University Press, 1995.

Swanson, Heather. Medieval Artisans: An Urban Class in Late Medieval England. Oxford: Blackwells, 1989.

Tawney, R. H., and Eileen Power, eds. Tudor Economic Documents. 3 vols, 1924.

Thrupp, Sylvia L. "Medieval Gilds Reconsidered." Journal of Economic History 2, no. 2 (1942): 164-173.

Unwin, Joan. "Apprenticeships and Freedoms: The Computer Analysis of the Records of the Cutlers' Company in Sheffield." Local Historian 25, no. 4 (1995).

Walker, M. J. "The Extent of the Guild Control of Trades in England C.1660-1820: A Study Based on a Sample of Provincial Towns 
and London Companies." Ph.D. Thesis, Cambridge University, 1986.

Webb, Cliff. London Apprentices. 44 vols. London: Society of Genealogists, 1996-2007.

An Index to the Association Oath Rolls for City of London, 1696.

Vol. 40. Basingstoke: West Sussex Family History Society

Record Series Publications, 2006.

Welch, Charles. History of the Worshipful Company of Pewterers of the City of London Based Upon Their Own Records. London: Blades East and Blades, 1902.

Westermann, W. L. "Apprentice Contracts and the Apprentice System in Roman Egypt." Classical Philology 9 (1914): 295-315.

Woodward, D. M. "Sources for Urban History. I. Freemen's Rolls." Local Historian 9 (1971): 92-93.

Yarborough, Alison. "Apprentices as Adolescents in Sixteenth Century Bristol." Journal of Social History 13 (1979), pp. 67-81. 


\section{LONDON SCHOOL OF ECONOMICS \\ DEPARTMENT OF ECONOMIC HISTORY}

WORKING PAPERS IN: THE NATURE OF EVIDENCE: HOW WELL DO "FACTS" TRAVEL?

For further copies of this, and to see other titles in the department's group of working paper series, visit our website at: http://www.Ise.ac.uk/collections/economichistory/

2005

01/05: Transferring Technical Knowledge and innovating in Europe, c.1200-c.1800

Stephan R. Epstein

02/05: A Dreadful Heritage: Interpreting Epidemic Disease at Eyam, 1666-2000

Patrick Wallis

03/05: Experimental Farming and Ricardo's Political Arithmetic of Distribution

Mary S. Morgan

04/05: $\quad$ Moral Facts and Scientific Fiction: $19^{\text {th }}$ Century Theological Reactions to Darwinism in Germany Bernhard Kleeberg

05/05: Interdisciplinarity "In the Making": Modelling Infectious Diseases Erika Mattila

06/05: $\quad$ Market Disciplines in Victorian Britain Paul Johnson

2006

07/06: Wormy Logic: Model Organisms as Case-based Reasoning Rachel A. Ankeny 
08/06: How The Mind Worked: Some Obstacles And Developments In The Popularisation of Psychology Jon Adams

09/06: $\quad$ Mapping Poverty in Agar Town: Economic Conditions Prior to the Development of St. Pancras Station in 1866 Steven P. Swenson

10/06: "A Thing Ridiculous"? Chemical Medicines and the Prolongation of Human Life in Seventeenth-Century England

David Boyd Haycock

11/06: Institutional Facts and Standardisation: The Case of Measurements in the London Coal Trade.

Aashish Velkar

12/06: Confronting the Stigma of Perfection: Genetic Demography, Diversity and the Quest for a Democratic Eugenics in the Post-war United States Edmund Ramsden

13/06: Measuring Instruments in Economics and the Velocity of Money

Mary S. Morgan

14/06: $\quad$ The Roofs of Wren and Jones: A Seventeenth-Century Migration of Technical Knowledge from Italy to England Simona Valeriani

15/06: Rodney Hilton, Marxism, and the Transition from Feudalism to Capitalism

Stephan R. Epstein

2007

16/07: Battle in the Planning Office: Biased Experts versus Normative Statisticians

Marcel Boumans

17/07: Trading Facts: Arrow's Fundamental Paradix and the Emergence of Global News Networks, 1750-1900 Gerben Bakker 
18/07: $\quad$ Accurate Measurements and Design Standards:

Consistency of Design and the Travel of 'Facts' Between Heterogenous Groups

Aashish Velkar

19/07: When Rabbits became Human (and Humans, Rabbits): Stability, Order, and History in the Study of Populations Paul Erickson and Gregg Mitman

20/07: Contesting Democracy: Science Popularisation and Public Choice Jon Adams

21/07: $\quad$ Carlyle and the French Enlightenment: Transitional Readings of Voltaire and Diderot

T. J. Hochstrasser

22/07: $\quad$ Apprenticeship and Training in Premodern England Patrick Wallis 